\title{
Does university have an effect on young people's active citizenship in England?
}

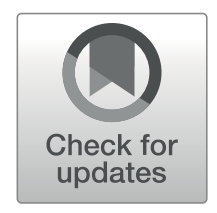

\author{
Jinyu Yang ${ }^{1} \cdot$ Bryony Hoskins ${ }^{2}$
}

Published online: 30 March 2020

(C) The Author(s) 2020

\begin{abstract}
Educational attainment measured by years of education has been widely reported as leading to higher levels of political participation. The theory is that education plays an important role in a person's civic skills and cognitive capacity that helps them understand and connect with the world of politics and be able to defend their interests (Nie et al. 1996). However, a number of studies argue that education has no effect on political engagement as educational attainment has been identified as a proxy for socioeconomic background and cognitive ability. In order to examine whether the university has an effect on young people's intentions for active citizenship in England, hybrid cumulative logit models are used in the Citizenship Education Longitudinal Study (CELS) 2009-2014 with between and within effects which help explain differences between individuals and within individuals at different time points. Control measures of previous citizenship education are also included in the analysis. We find that the university has a positive independent effect on intentions to vote, a negative effect on intentions to volunteer, but not on intentions to protest in the future for young people in England. These findings help clarify the role of higher education (HE) in developing and maintaining democracy and social cohesion.
\end{abstract}

Keywords Citizenship · Higher education · Hybrid cumulative logit models

\section{Introduction}

There is a considerable amount of literature that shows the connections between education and political engagement or democracy (Milligan et al. 2004; Pattie et al. 2004). Specifically, Almond and Verba (1963) claim that educational attainment seems to have the most important

Jinyu Yang

Dr.Jinyu.Yang@outlook.com

1 School of Education, University of Southampton, Southampton SO17 1BJ, UK

2 Department of Social Sciences, University of Roehampton, London SW15 5PU, UK 
statistical effect on political attitudes, compared with other variables including gender, place of residence and occupation. Putnam (2000) also claims the relationship between education and citizenship by stating that education is a very important and powerful predictor of political engagement. Even so, there is limited research on the particular effect of higher education ${ }^{1}$ (HE) on diverse forms of engagement (Veugelers et al. 2014).

Recent changes in HE have positioned universities centrally within market capitalism (Brown 2013). These changes include the rise in tuition fees and greater student choice (Brown 2013). Universities in this context have to prove their economic value to students in particular in terms of employability and student satisfaction (Brown 2013). This has led to a number of questions being asked about universities today: What is the university for? What roles should HE take? This is still in debate. While higher education is widely regarded as a tool for individual economic returns and national economic development, it is also advocated to be strongly related to social cohesion, equity and democracy, as well as the empowerment of individuals (Veugelers et al. 2014). However, in the UK, the role of HE in enhancing democracy and social cohesion has been historically neglected (Annette 2010), and this paper will establish with greater clarity the role universities are currently playing on young people's intentions to participate politically and civically.

Nevertheless, according to Sloam (2013), the large participation gap between college students and other young people indicates the great importance of universities and colleges in enhancing civic and political engagement. A longitudinal study comparing two cohorts (1958 and 1970) and across ages (1958 cohorts) finds that graduates show a higher probability of voting in general elections, and higher rates of participation in voluntary organisations (Bynner et al. 2003). Meanwhile, some studies have also used different methods to examine whether education has a causal effect on political participation; however, most of them have mainly focused on voting and protesting (see literature in Persson 2014). Also, few studies employ longitudinal data including measurements of the dependent variable before the educational episode or intervention of interest to investigate the effects of education on political engagement (Hoskins and Janmaat 2016). These studies can better draw causal relationships than those relying on cross-sectional data or on longitudinal data without prior measures of the outcome (Persson 2012). Therefore, it is imperative to study the effects of higher education on citizenship with larger and preferably nationally representative longitudinal data. This would provide a better and broader, even though still not conclusive, assessment of the net effect of a phase of education and of the durability of this effect (Paterson 2009; Janmaat et al. 2014).

This article makes the following contributions to the discussion. Firstly, this article situates in the intersection of education and political science, and contributes to both disciplines. It extends the research on political participation to active citizenship including both political and civic participation, and uses hybrid models to identify a relationship between education and active citizenship intentions. Secondly, the study uses the latest nationally representative longitudinal data in England and tests different theories about education and citizenship. This study advances beyond the current research in the field as the analysis includes measures of young people's intention to engage prior to entering, during and after HE experiences. Thus, this research

\footnotetext{
${ }^{1} \mathrm{HE}$ includes a wide range of levels of education and qualifications, such as first degrees, Higher National Diplomas (HNDs) and foundation degrees. In this study, however, higher education refers to getting a degree in the university setting as this reflects the data collected in this study.
} 
advances knowledge towards establishing a relationship between education and forms of active citizenship.

In the article, we first review theories concerning active citizenship as well as the relationship between higher education and active citizenship, and propose the hypothesis to be tested. Then, we explain the method used in the study, introduce the dataset and outline the variables used. After that, we present the results of the test and conclude with a discussion.

\section{Active citizenship}

Active citizenship is the concept of engagement used in this article. Citizenship is a contested and developing concept that is used widely in research, policy and teaching of citizenship education (Kerr and Nelson 2006; Kennedy 2007). Kerr and Nelson (2006) places emphasis on the behavioural processes of active citizenship required to enable and maintain citizenship, and describe how active citizenship is fundamentally about engagement and participation in society and focuses on participation in both civil and civic society. Also, the concept of active citizens includes having civic, political and social rights through participatory practices at various levels (Haahr 1997). This concept refers to acquiring rights through engagement in political and social contexts and production of common demand in daily life. Furthermore, citizenship means much more than political involvement as it also involves a wide range of voluntary activities, including 'informal activities with friends, relatives and neighbours and formal membership in various organisations' (Pattie et al. 2004, 24). Therefore, Hoskins $(2006,6)$ defines active citizenship as 'participation in civil society, community and/or political life, characterised by mutual respect and non-violence and in accordance with human rights and democracy'. Based on these arguments, this article describes active citizenship as an action in political life — voting and protest, and activities in civil society or community volunteering.

First of all, voting is representative democracy, which is generally seen as one of the most important manifestations of democracy where citizens are able to influence the government and political decision-making (de Weerd et al. 2005). Elections are important as 'they select political elites, provide a source of democratic legitimacy, and engage the mass public in the democratic process' (Dalton 2015, 102).

Furthermore, many researchers have found that the scope of political participation has extended, and include protest as an important form (Meyer and Tarrow 1998; Roefs 2003, cited in de Weerd et al. 2005). Protest activities, a more intensive form of participation, aim to act or express a voice to influence decision-making. It serves as a critical voice of democratic process and makes the government accountable. Protest can focus on specific issues or policy goals - from protecting the environment to protesting the local policies - and 'can convey a high level of political information with real political force' (Dalton 2015, 55).

Also, researchers contend that the pattern of citizenship is changing, and more and more young people are in favour of voluntary participation (Dalton 2015; Pattie et al. 2004). Therefore, volunteering is also regarded as a key part of civil society (Dekker and Halman 2003), which is believed to make a contribution to the community (de Weerd et al. 2005). It is one of many forms of citizen participation (Verba et al. 1995) and is important for active citizenship. Therefore, the article uses these three dimensions to measure active citizenship.

From previous literature, we can be aware of the importance of $\mathrm{HE}$ in promoting active citizenship, and then comes the question: how can higher education influences active citizenship? This is discussed in the following section. 


\section{How can higher education influence active citizenship?}

This section firstly discusses the links between education and citizenship, and then explores the causal mechanisms in HE that promote students' active citizenship.

$\mathrm{HE}$ can be argued to be important for political participation because it can provide more knowledge, skills, attitude and political familiarity for individuals to participate in more complex political activities (Verba et al. 1995; Hillygus 2005; Campbell 2006). Building on these theories, researchers suggest that HE does not only prepare a citizen to vote, but also helps them to have 'a reasoned and deliberative decision making' process and could promote the cognitive skills that are necessary to gain, process, and analyse political information (Hillygus 2005, 27), while other researchers claim that increased knowledge helps improve motivation and provides the opportunity to practice citizenship (Delli Carpini and Keeter 1996; Nie et al. 1996).

Campbell (2006) refers to the above cognitive developmental models as the absolute education model. The model states an individual's own level of education is the driving mechanism of their political and civic engagement. Campbell employs the European Social Survey (ESS) to test the absolute education model in multiple European nations, and finds strong evidence for it in voting, expressive political activity (protesting) and voluntary association. Nevertheless, the ESS data used is cross-sectional and can only be used to demonstrate associations rather than causality.

The absolute educational model serves as a start point for investigating the links between education and active citizenship. However, it is not sufficient in explaining the causal mechanisms in a university setting. In this sense, two strands of literature from the education research and political science research may be weaved together to better theorise the causal mechanisms of how HE influences students' active citizenship.

From the perspective of education research, there is an increasing theoretical and empirical literature which regards students as 'academic citizens' and explores two questions: how practices and social environment in the university affect student participation in academic governance, and how this promotes their political behaviour outside of the university. As for the political science research, much literature has contributed to the theories, especially those theories that rely on the effects of mobilisation, social networks, civic norms and institutions on electoral turnout. The rest of this section explores how different practices and social environments in university settings may affect students' citizenship from the perspectives of both disciplines. Specifically, the effects of student representation, student union and societies, as well as curriculum and academic staff are discussed.

\section{Student representation in shared governance}

Universities are thought to be 'sites of democratic citizenship', and student representation is regarded as a means to learn democratic values and practice democratic citizenship (Boland 2005; see also Bergan 2004; Plantan 2002). Consumerist commitments offer provisions to student representation to voice their interest, and provide input and feedback into the learning process (Luescher-Mamashela 2013). In this sense, HE plays an important role in supporting the democratic socialisation process, by recognising students' participation rights as members of university and as citizens (Luescher-Mamashela 2013).

In academic elections of student representatives, student participation serves as a form of expressing student interest and voice like the elections in democratic societies (Kouba 2018). 
Also, stressing social norm on campus such as turning out in students and academic elections can be very likely to lead to norm-conforming behaviour (Gerber and Rogers 2009). Student representation is also an important way to practice democratic citizenship in the context of shared governance in HE (Boland 2005), where students successfully represent their groups on related high-level institutional committees and being recognised as members of the university and as citizens (Luescher-Mamashela 2013).

\section{Student union and societies}

In universities, non-politics are provided opportunities to receive political ideas, to participate in debates, and to engage in civic activities more broadly. (Loader et al. 2015). Studies generally recognise the value of student societies and groups. Student societies supported by the student union are a focus of politicisation as they not only offer the essential resources for mobilising students, maintaining their interests and developing their organisational skills necessary for future civic engagement, but also crucially provide the networked environment in which young people can experience various contemporary political practices and repertoires (Loader et al. 2015).

Political science theories also help explain why student union and societies in universities promote political engagement. Theory of mobilisation regards voting as social behaviour led by social norms and sanctions (Arceneaux and Nickerson 2009; Gerber and Green 2000). Citizens are motivated to participate in politics by candidates, parties, interest groups and new social movements (Rosenstone and Hansen 1993), which reduces the costs of political participation by providing information about candidates, parties and electoral processes (Smets and Ham 2013). Therefore, voter turnout is related to the involvement in associational life such as being members of organisations including political party, social association and sports club (Smets and Ham 2013).

By applying the theory of mobilisation in HE, it is evidenced that the universities provide extensive opportunities for students to participate in and be members of groups such as student council, student societies and clubs. These opportunities motivate students to participate and cultivate their political habitus (Loader et al. 2015). Especially, the milieu of those small student societies is very important to develop the habitus of the student citizen (Loader et al. 2015). From the perspective of education, small student societies provide opportunities for students to develop political self, affiliation to particular fields and access to cultural and social capital (Loader et al. 2015). Meanwhile, political science research provides both theoretical and empirical evidences that small communities promote opportunities for participation in democracy (see Dahl and Tufte 1973, Ryšavý and Bernard 2013, Erk and Veenendaal 2014 cited in Kouba 2018). Specifically, the social sanctions and norms in small communities create more pressure and incentives, which effectively builds up shared social identity and motivate voting and participation behaviours of the students (Knack 1992; Funk 2010; Kouba 2018; Bolden et al. 2014).

The positive effect of social mobilisation on voting behaviour may happen between close friends with a face-to-face relationship (Bond et al. 2012). This effect is more likely to occur in the university as students have more opportunities to develop close relationship with their classmates, roommates or other students in the same group or society. Therefore, it is much easier for them to be influenced by their friends in daily lives and voting behaviour. These close relationships can help spread political information among students' social networks and motivate students to vote. Apart from face-to-face interactions, processes of politicisation 
mediated by social media networks play an increasingly important role in facilitating political habitus (Loader et al. 2015).

\section{Academic staff and curriculum}

Universities are an important place for students to learn political knowledge from socialising with their peers, staff and lecturers. This is supported by theory of socialisation, which considers the impressionable or formative years between childhood and adulthood a key period for citizens to form the basis of political attitudes and behaviour (Plutzer 2002). In universities, the political learning takes place in/through various socialising agents, including previous mentioned peer students and the academic staff (Smets and Ham 2013).

The shared identities of academics may motivate an active role in leadership, management and governance activities (Bolden et al. 2014). The academic staff's attitude towards democratic and participatory pedagogies, including membership or partnership in teaching and learning, may have an influence on the students' co-determining aspects of teaching and learning (Luescher-Mamashela 2013).

The interactions between academic staff and university students are also reflected in the delivered curriculum, which may transfer democratic values that promote critical thinking and tolerance of different views, to university students (Boland 2005). Specifically, the curriculum may offer students democratic experiences in tutorials, seminars, group projects, service learning and active learning (Boland 2005).

\section{An alternative hypothesis}

\section{Education as a proxy}

Even though it seems that most researchers in the education field have reached an agreement that education has influenced civic and political engagement, there are some scholars within economics and political science that argue that education is simply a proxy for socioeconomic background, and/or cognitive ability (Nie et al. 1996; Persson 2014). The theory of the effect of social economic background as the primary influence of political engagement claims that as different social classes have different political and education norms, it is the early family socialisation into these norms that influence both political engagement and the importance of education.

Persson (2014) uses quantitative analysis with data from the 1970 British Cohort study and concludes that educational attainment merely proxies for people's socioeconomic background and social experience within the family rather than being a cause of political participation. He also claims cognitive ability, cultural activities and parents' education are strong predictors for both educational attainment and political participation from the analysis. This hypothesis suggests that individuals with higher cognitive ability will be more likely to go to higher educational institutions and will simultaneously tend to participate more in political engagement. Herrnstein and Murray $(1994,235)$ argue that 'education predicts political involvement in America because it is primarily a proxy for cognitive ability'. All these studies mainly focused on political participation, particularly voting, while our study extends to active citizenship. Also, if education only serves as a proxy for these early social experiences or cognitive ability, young people should have established political engagement before receiving 
HE. Therefore, this study has taken prior active citizenship intentions into account to test these theories.

In this study, in order to examine the theories of HE as a proxy or as a cause for active citizenship, we control people's socioeconomic status, parents' education, individual's innate ability and other variables by two methods:

1. Using longitudinal data

2. Using within effects on citizenship educational longitudinal data

Based on the theoretical discussion, the hypothesis tested in this article is that the university can promote young people's active citizenship intentions, including voting, protesting and volunteering.

\section{Data and method}

This section starts with an introduction to the CELS data. Next, it reviews the analysis methods-ordinal logistic regression and hybrid models, followed by analysis procedure and instruments used. Lastly, it introduces the variables used in the analysis.

\section{CELS data}

Our analysis is based on data drawn from the last three waves of the CELS data. The longitudinal data are from 2009 to 2014 and only cover England. The initial aim of the CELS data focused on citizenship education, and then it moved to examine young people's active citizenship and to investigate the factors contributing to different types and levels of engagement (TNS BMRB 2015). The longitudinal data include a wide range of variables measuring factors through school and adulthood, which have not been used by previous studies in the field. Therefore, this provides the opportunity to better investigate HE's effect on active citizenship.

The citizenship items are taken from the three waves. The citizenship is measured by young people's intention to vote, protest and volunteer in the future in waves 4, 5 and 6. Some studies use instrumental variables to predict education attainment (Milligan et al. 2004); however, this article is in a better position by using higher education as the predictor variable. The higher education variable is measured by the following question: 'Did you get a degree or above, or are you doing a degree at university or not?'. Citizenship education before university is also taken into account. As it changes from wave 4 to wave 5, so it is included in the model. Also, in order to remove the effect of time, we add the dummy variable of time into the model. Other observed background variables such as gender, ethnicity, books at home, parents' education level and parents' socioeconomic classification (occupation) are used as control variables (see Fig. 1). By adding fixed effects in longitudinal data analysis, the effect of unobserved individual background can also be omitted. The detail of this is elaborated in the following parts.

\section{Attrition}

As with other longitudinal datasets, the CELS dataset is also experiencing attrition. In wave 4, there were 1388 respondents. A large proportion of participants dropped out in wave 4, when 


\begin{tabular}{|c|c|c|c|c|c|}
\hline Variables & Values & \multicolumn{2}{|c|}{ Wave 4 in 2009} & Wave 5 in 2011 & Wave 6 in 2014 \\
\hline Vote & \multirow{3}{*}{ definitely not do $=1$} & \multicolumn{2}{|l|}{15} & 8 & 9 \\
\hline protest & & \multicolumn{2}{|l|}{39} & 30 & 41 \\
\hline volunteer & & \multicolumn{2}{|l|}{8} & 2 & 4 \\
\hline Vote & \multirow{3}{*}{ probably not do $=2$} & \multicolumn{2}{|l|}{37} & 18 & 23 \\
\hline protest & & \multicolumn{2}{|l|}{102} & 94 & 105 \\
\hline volunteer & & \multicolumn{2}{|l|}{40} & 14 & 19 \\
\hline Vote & \multirow{3}{*}{ probably do $=3$} & \multicolumn{2}{|l|}{134} & 103 & 80 \\
\hline protest & & \multicolumn{2}{|l|}{113} & 242 & 127 \\
\hline volunteer & & \multicolumn{2}{|l|}{182} & 174 & 167 \\
\hline Vote & \multirow{3}{*}{ definitely do $=4$} & \multicolumn{2}{|l|}{118} & 190 & 203 \\
\hline protest & & \multicolumn{2}{|l|}{34} & 41 & 32 \\
\hline volunteer & & \multicolumn{2}{|l|}{58} & 115 & 117 \\
\hline \multirow{2}{*}{ University } & Yes & \multicolumn{2}{|l|}{0} & 191 & 181 \\
\hline & No & \multicolumn{2}{|l|}{322} & 131 & 141 \\
\hline \multirow{2}{*}{$\begin{array}{l}\text { Citizenship } \\
\text { Education }\end{array}$} & Yes & \multicolumn{2}{|l|}{193} & 311 & 311 \\
\hline & No & \multicolumn{2}{|l|}{86} & 5 & 5 \\
\hline Age & & $17-18$ & & $19-20$ & $22-23$ \\
\hline & Male & & 105 & & \\
\hline Gender & Female & & 217 & & \\
\hline & White & & 265 & & \\
\hline Etrinicity & Others & & 57 & & \\
\hline & More than 200 books & & 85 & & \\
\hline & Books (101-200) & & 72 & & \\
\hline Donation & Books $(51-100)$ & & 73 & & \\
\hline Books in Home & Books (11-50) & & 63 & & \\
\hline & Books (1-10) & & 26 & & \\
\hline & 0 Books & & 3 & & \\
\hline & left full-time education & ore 16 & 144 & & \\
\hline $\begin{array}{l}\text { Mother's } \\
\text { education level }\end{array}$ & left full-time education & er school & 73 & & \\
\hline & Studied at university/g & degree & 62 & & \\
\hline & left full-time educatio & ore 16 & 149 & & \\
\hline $\begin{array}{l}\text { Father's } \\
\text { education level }\end{array}$ & $\begin{array}{l}\text { level left full-time edu } \\
\text { school }\end{array}$ & n after & 75 & & \\
\hline & Studied at university/g & degree & 61 & & \\
\hline & Professional or higher & nical work & 57 & & \\
\hline & Manager or Senior Ad & strator & 28 & & \\
\hline & Clerical & & 44 & & \\
\hline Mother's & Sales or Services & & 46 & & \\
\hline & Semi-skilled or Unskill & lanual Work & 32 & & \\
\hline & Homemaker/carer in t & ome & 82 & & \\
\hline & Others & & 30 & & \\
\hline & Professional or higher & nical work & 57 & & \\
\hline & Manager or Senior Ad & strator & 52 & & \\
\hline Father's & Sales or Services & & 15 & & \\
\hline occupation & Skilled Manual Work & & 63 & & \\
\hline & Semi-skilled or Unskill & lanual Work & 43 & & \\
\hline & Others & & 75 & & \\
\hline
\end{tabular}

Fig. 1 Descriptive statistics of variables 
many students went to university or left education. The data collection in wave 5 have already reduced the effect of attrition. We get 322 individuals for the three waves. In order to test for potential attrition effects, we followed Eckstein et al. (2012) and Keating and Janmaat (2016), and compare participants in all three waves with those who just participated at wave 4. Significant differences were found in measuring the attrition effects for gender with more female respondents taking part in waves 5 and 6 than respondents who just participated in wave 4 . In order to deal with the attrition issues and make the data nationally representative, weighting is applied to gender, ethnicity and region of young people in England. As these proportions may change over time, the weight variable was created in SPSS using rim weight according to the data from national statistics in the years 2009 (the fourth wave of CELS data), 2011 (the fifth wave) and 2014 (the sixth wave). The weight helps the data match the target population. In addition, the gender variable, as well as other background variables, was also included in our statistical analysis as controls, which helps to counterbalance any remaining skew that cannot be addressed by weights (Paterson 2013).

To prevent further data loss due to item non-responses, this article uses the Bayesian estimation technique of multiple imputation (MI) in SPSS to impute data. This method may utilise all the variables in the analytical model to impute the missing values and create ten imputed datasets, from which the final parameters are obtained by averaging. Also, MI can address non-random missingness as it generates datasets according to the observed values for individuals and the relations observed in the data for other participants (cf. Schafer and Graham 2002).

This dataset is the only longitudinal data available that could provide insights into the effects of universities on citizenship. With repeated observations for the same individual over time, the longitudinal data enable us to address the issue of causality and to control for unobserved individual characteristics that are time-invariant, but correlated with citizenship (Winkelmann and Winkelmann 1998).

\section{Analysis methods}

For our study, hybrid cumulative logit models (Allison 2009) are created to explore whether the university has an impact on young people's future active citizenship. The model in this study is an ordinal logistic regression with between and within individual effects. This regression is appropriate for the study as the dependent variables - intentions for future active citizenshipwere ordinal, that is, definitely to do, likely to do, not likely to do and definitely not to do.

In order to get a precise result, we also add between and within effects on the ordinal logistic regression model. The hybrid models allow us to have two coefficients estimated for each variable: a between-individual effect (equal to the random effect) and a within-individual effect (equal to fixed effects). A random-effects model is estimated with all the time-variant covariates such as university and previous citizenship education demeaned and their deviations calculated; therefore, it provides the fixed-effects estimators. Meanwhile, time-invariant covariates (control variables), for example, parents' educational level, have not changed in the model and thus equal to the random-effects estimates.

Specifically, the between-individual effect estimator uses variance between individuals. The estimator is to estimate a regression on the dataset of means which consist of the personspecific mean of each variable across time. With the between-individual effect model, we are able to examine the impact of HE through the difference between individuals. However, the between-individual effect estimators are probably biased by unobserved characters. 
The within-individual effects only employ within-individual variation to estimate coefficients, which enables us to analyse changes across time. Adding within-individual effects allows us to counter omitted variable bias, for example, some researchers thought that an individual's cognitive ability or other unobserved variables also influenced political engagement. With within-individual effects, the time-invariant unobserved heterogeneity is eliminated as fixed-effects control all these differences by removing the idiosyncratic error term (Halaby 2004). Therefore, by comparing these two effect estimators, we can better understand how universities influence young people's intentions for active citizenship.

\section{Modelling procedure}

The hybrid models were run with Stata, and we followed the procedure described by Allison (2009). The hybrid model requires us to combine the fixed-effects and random-effects approaches into a single model. According to Allison $(2009,39)$, this can be done through "decomposing each time-varying predictor into a within-person component and a betweenperson component", followed by creating a random-effects model with both components. The estimates for the mean variables are not enlightening in themselves. However, it is important to include these variables as they help get better estimates of the effects of the other timeinvariant variables.

The models were created in Stata, and the results are shown in Fig. 3. The coefficients for the cumulative logit model represent the change in the log-odds of being in a higher rather than a lower category of the dependent variable.

\section{Variables}

The section introduces variables in the analysis, and the descriptive statistics of each variable can be seen in Fig. 1.

\section{Dependent variables}

As the analysis method requires variables to exist in each time point, the variables of actual action, for example, voter turnout, cannot be used as indicators for political engagement because young people cannot vote before 18 and national elections happen about every 5 years. Therefore, to measure young people's active citizenship, we will depend on their intentions on political and civic activities: voting, protest and volunteering as research shows the participatory intentions, reported participation and validated participation are closely correlated (Achen and Blais 2010). The three items, repeated in each wave, were asked as the following questions, respectively: 'In the future will you - Vote in general elections?'; 'If you were confronted by something you thought was wrong would you - Take part in a non-violent protest march or rally?'; 'In the future will you - Volunteer time to help other people?'

\section{Predictor variables}

In this study, we would like to know the effect of universities on active citizenship. In the dataset, respondents were asked what the highest qualification they achieved in each wave 
was. In wave 5, they were also asked if they were doing a university degree. For the analysis, we constructed a dichotomous variable as the predictor variable in each wave: 'Do you have a university degree (or above) or are you doing a university degree?' ( $1=$ Yes, $0=$ No).

\section{Control variables}

Some other factors are reported to influence young people's political and civic engagement, such as social economic background (Colby et al. 2007), gender and ethnicity (Vromen 2003; McFarland and Thomas 2006). In order to separate the effect of universities from young people's background factors, we include controls for gender, ethnicity, parental education level and occupation, as well as the number of books in the home. Young people's citizenship education at school is also a factor (Colby et al. 2007). To remove the influence of previous citizenship education, their citizenship education before university $(1=$ Yes, $0=$ No $)$ is also controlled. Additionally, the longitudinal data enable us to separate differences between groups that were developed by previous differences unrelated to the influence of universities. With fixed effects, the time-invariant variables like innate characteristics - for example, cognitive ability — can also be controlled.

\section{Results}

First of all, we start with a descriptive analysis, and Fig. 1 shows the young people's intentions for voting, volunteering and protesting in different educational level. In each intention, two lines are plotted with dots: The solid lines represent the intentions of young people who have already obtained the university degree while the dashed lines describe the intentions of young people who have not gone to universities; the dots indicate the young people's intentions in three time points (both groups in secondary school, at university or after secondary school but not at university, and after university or after secondary school but not at university).

As is shown in Fig. 2, there are clear differences in citizenship intentions between the two educational groups. However, these differences appear to be present in both secondary school and after university time points and the trends of each group are similar. This does not support a causal effect of education: Differences across educational groups do not seem to result from experiencing higher education, but already exist before higher education. Within each group, voting intentions of young people with higher education increase while volunteer and protest intentions decrease. Also, young people without higher education experience an increase in their active intentions but their intentions' levels are still below their peers with higher education degrees. Therefore, in order to better examine how young people's citizenship intentions change over higher education, we proceed with ordered logit hybrid models with between- and within-effects.

Figure 3 shows the results of ordered logit hybrid models. It presents the effects of universities on intentions to vote, protest and volunteer in the future. The coefficients for the models stand for the change in the log-odds of being in a higher category of the dependent variable. For within-effect, the university has a statistically significant effect on intentions to vote. An individual is more likely to express an intention to vote after $\mathrm{HE}$ when other variables are controlled. These results are consistent with educational attainment theory that an individual's level of education is a driving force for political engagement. For the intention to volunteer, the trend is different when other variables are controlled. Young people are less 


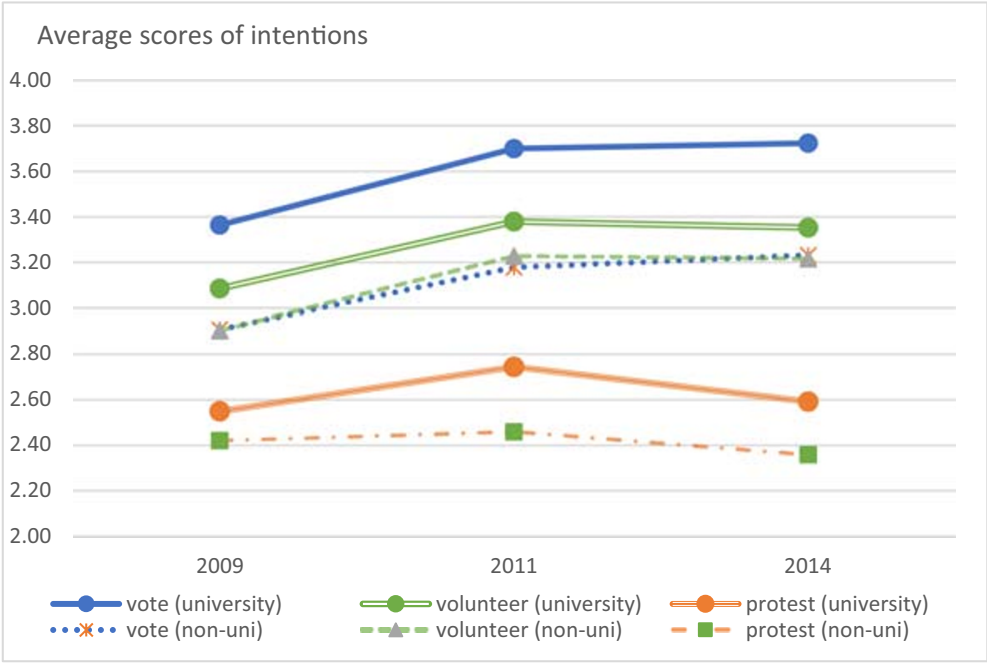

Fig. 2 Young people's intentions (measured on a scale from 1 to 4 ) and university status

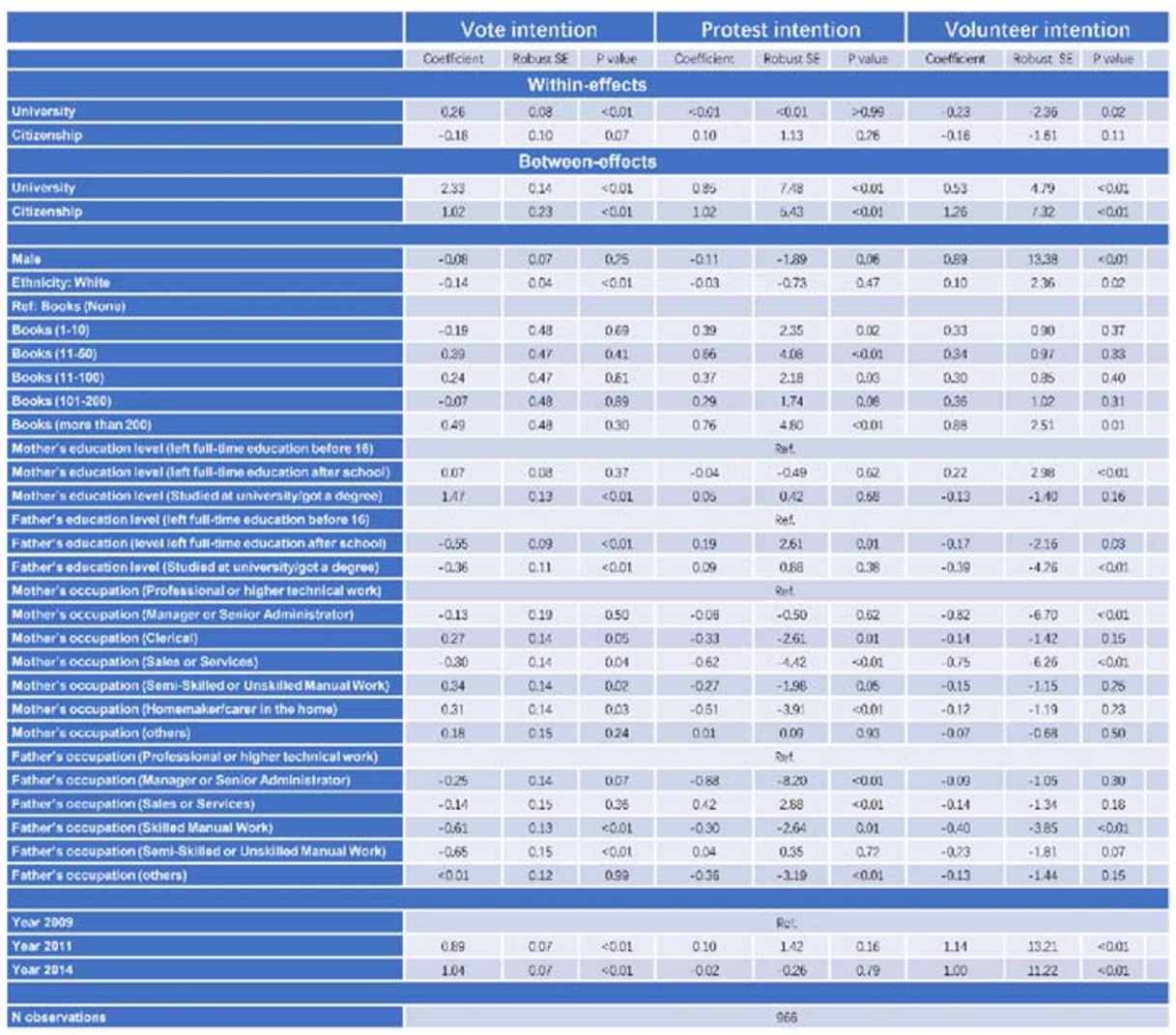

Fig. 3 Hybrid logistic models predicting young people's intentions for active citizenship 
likely to promote their intentions to volunteer after HE. Meanwhile, the result of the protest is not significant, which indicates that $\mathrm{HE}$ has no effect on protesting intentions. This is also a noteworthy finding as it suggests that young people do not increase their intentions to protest after their experience in higher education.

For the between-individual effects, all variables are significant, as the test of the equality of fixed effect and random effects shows that we can rely on the results of within effects. Therefore, universities have a positive influence on young people's intentions to vote. This indicates the important impact of HE on voting which is in line with previous research. Young people with HE degree are related to a higher likelihood of voting intentions in the future than their peers without HE.

All the findings are robust with observed and unobserved control variables within hybrid models, which means they are significant in the presence of a variety of controls designed to measure the social backgrounds and status of the individuals. Also, these findings are in line with the descriptive analysis results in Fig. 2: young people with higher education experience an increase in their voting intentions, a decrease in volunteer intentions, but their intentions' levels are still higher than their peers without higher education degrees. The implications of these findings for citizenship education in HE in the UK are discussed in the final section.

There are some limitations to our analysis. Due to the attrition in the data, there might be selection effects. However, attrition effects were only found in gender in the method section, and we deal with them by including gender and other background variables in the analysis, weighting and multiple imputation. Even though we are aware that there may be differences between fulltime and part-time students as well as of different disciplines, the data available does not provide any information about these differences. Therefore, the study examines university students as a whole including students both full-time and part-time across all disciplines.

\section{Discussion and conclusion}

This study examines the effect of universities on students' intentions to be active citizens in England, and supports the hypothesis that the university can promote voting intentions. Meanwhile, the quantitative analysis indicates that universities reduces volunteering intentions and rejects significant relationship between university and protesting intentions. These new findings may lead to further research about the effects of university on active citizenship in the UK.

As discussed in the earlier section, the data and methods we used help identify a causal direction of the relationship and take the effects of previous citizenship education into account. Therefore, our results suggest that HE has an independent positive effect on young people's intentions to vote in the future. This provides strong support to the theory that educational attainment leads to a high level of voting. Also, the voter turnout in general elections is consistent with the findings. The data that we have used is from 2009 to 2014, which is close to the 2010 and 2015 general elections in the UK. In the 2010 election, young people with degrees (75\% of 18-34-year-olds) have a much higher voter turnout than their peers with less education (44\% with GCSE or less of 18-34-year-olds) (Berry and Mcdonnell 2014). There is a similar result of the 2015 election; there was approximately $40 \%$ difference in voter turnout ratio between young people with and without degrees (Gardiner 2016). These differences were smaller in the 2017 general election (69\% versus 61\%) (Ipsos MORI 2017) but this may be due to the recent political context - a heated debate on the UK leaving the European Union after its referendum in 2016 - and larger youth vote in the recent election in the UK. 
However, we find no significant effect for intentions to protest and significantly negative effect for intentions to volunteer. This finding is a unique contribution to the study. Even though there are traditionally low levels of protest in Britain across all groups, a possible explanation for the finding might be that universities today are less of an environment that is conductive to motivating social causes and more about developing a consumer mindset (Brooks et al. 2015). This comes with the influence of neoliberalism on HE, of which the marketisation trend of universities is a reflection. For example, the marketisation of the university is reflected through tuition fees and competition for students (Brown 2013). Since 2012, universities are allowed to raise the tuition fees up to $£ 9000$, which is one of the key developments in the marketisation of UK higher education (Brown 2013). In this case, university students will graduate with a large amount of debts; therefore, they would expect to have decent salaries with university degrees (Brown 2013). With the continuing increase in tuition fees in universities in England, there is a possibility that this trend brings about a consumer mindset among students in HE and also strengthens the perception of value for money in HE. On the one hand, even though HEIs in England still receive funding for teaching from a combination of grants and tuition fees, from 2012, their income for teaching will mostly come from fees (Brown 2013). On the other hand, it is possible that the recent removal of student number controls in universities will have a considerable impact on the demands of students as they have more choices of universities (Buckley et al. 2015). It is reported that the student enrolment has greatly risen in some universities, especially Russell Group universities (24 excellent public research universities) while falls significantly in other universities, for example, some post-92 universities (former polytechnic or central institutions in the UK that were granted university status in 1992) (Morgan 2016). Consequently, universities have to compete for students, therefore, they are becoming more responsive to students' needs and expectations. Giroux (2011) argues that weak forms of political protest and a conservative political climate on US campuses is associated with students' commodification of their lives. In addition, demands for satisfaction introduced in universities imply that 'teaching should confirm what the student believes, rather than challenging students' assumptions in an intellectual process of transformation' (Williams 2013, 100) which may well be associated with the motivation to protest. This leads us to speculate that universities in the UK are possibly now also more of a conservative environment promoting more traditional forms of engagement that can maintain the status quo such as voting.

For volunteer intentions, young people are less likely to improve them after HE even though students with HE have higher intentions than their peers without HE degree. This might because the increased tuition fee and living costs force students to seek income from part-time jobs, which leave them limited time to volunteer. The 2015 Endsleigh annual student survey suggests that the proportion of students working to fund studies has increased significantly: about $77 \%$ of students depend on income from employment from 59\% in 2014 and 57\% in 2013 (Dennis et.al. 2018). The study found that one-third of the students work parttime, and another $14 \%$ work full-time, during study breaks or term time or both (Dennis et al. 2018). Research has shown that the motivations for students to volunteer are twofold, compassion and concern for others, as well as perceived enhanced employability for themselves (Williams et al. 2017). As students are under financial pressure, they may tend to develop skills from paid jobs rather than volunteer experience. In particular, the current sociopolitical climate of austerity and marketisation of HE may reinforce the situation.

This raises an important question on the balance among different roles of HE in the UK in the future: Is HE taking more responsibility for promoting social equity and democracy or more for pursuing financial purposes? Additionally, there is evidence from research indicating that youth are 
not encouraged to develop projects that can bring social change as these projects may challenge existing institutions (Dolan and Brennan 2016). Therefore, youth civic engagement usually focuses on maintaining these institutions rather than encouraging their action for change (Dolan and Brennan 2016). Further research is needed to substantiate the relationship between the changes to the university environment and the changes to the norms of civic and political engagement.

Another major important question left to ask is why HE has an important effect on voting intentions. This is not answered by our findings. Some researchers argue that HE is important for active citizenship as it can provide more knowledge, skills and political familiarity for individuals to participate in more complex political activities (Hillygus 2005). It does not only prepare a citizen to vote but also helps them with 'reasoned and deliberative decision making' (27). Also, it is argued that the liberalising and politicising effect of university occurs through a process of mixing with people from various backgrounds and perspectives, being open-minded and engaging in a variety of topics (Abrahams and Brooks 2018). Glaeser et al. (2007) argue that education socialises young people and political engagement is one form of socialisation; therefore, education raises political or civic participation.

However, this research question remains open and needs further research. This is especially the case since our study considers the university as a similar experience for everybody, while we need to acknowledge it may not be the case. Consequently, the effects of universities on citizenship intentions could be possibly related to the different types of universities, different subjects, and full-time or part-time programmes. For example, students in Russell group universities may have a different experience with others in more modern universities. With all the variation in experiences, it is difficult to establish more precise theories why the association exists. Future quantitative and qualitative research is needed to ascertain HE experiences that may affect young people's citizenship intentions. This research would need to identify the effect of different subjects and curricula at the university, alongside identifying the effects of activities such as clubs and the role of the student unions on young people's active citizenship.

Open Access This article is licensed under a Creative Commons Attribution 4.0 International License, which permits use, sharing, adaptation, distribution and reproduction in any medium or format, as long as you give appropriate credit to the original author(s) and the source, provide a link to the Creative Commons licence, and indicate if changes were made. The images or other third party material in this article are included in the article's Creative Commons licence, unless indicated otherwise in a credit line to the material. If material is not included in the article's Creative Commons licence and your intended use is not permitted by statutory regulation or exceeds the permitted use, you will need to obtain permission directly from the copyright holder. To view a copy of this licence, visit http://creativecommons.org/licenses/by/4.0/.

\section{References}

Abrahams, J., \& Brooks, R. (2018). Higher education students as political actors: evidence from England and Ireland. Journal of Youth Studies., 22(1), 108-123.

Arceneaux, K., \& Nickerson, D. W. (2009). Who is mobilized to vote? A re-analysis of 11 field experiments. American Journal of Political Science, 53, 1-16.

Achen, C.H. \& Blais, A. (2010). Intention to Vote, Reported Vote and Validated Vote. Paper presented at the APSA 2010 Annual meeting, Orlando FL, May.

Almond, G., \& Verba, S. (1963). Civic Culture. Princeton: Princeton University Press.

Allison, P. D. (2009). Fixed effects regression models. Thousand Oaks: Sage.

Annette, J. (2010). The challenge of developing civic engagement in higher education in England. British Journal of Educational Studies, 58(4), 451-463. 
Bergan, S. (2004). Higher education governance and democratic participation: the university and democratic culture. In S. Bergan (Ed.), The university as res publica: Higher education governance, student participation and the university as a site of citizenship (pp.13-30). Strasbourg: Council of Europe.

Berry, R. \& Mcdonnell, A. (2014). Highly educated young people are less likely to vote than older people with much lower levels of attainment. Democratic Audit and London School of Economics, 13 March 2014. http://www.democraticaudit.com/?p=2752. Accessed 13 October 2017.

Bolden, R., Gosling, J., \& O'Brien, A. (2014). Citizens of the academic community? A societal perspective on leadership in UK higher education. Studies in Higher Education, 39(5), 754-770.

Bond, R. M., Fariss, C. J., Jones, J. J., Kramer, A. D., Marlow, C., Settle, J. E., \& Fowler, J. H. (2012). A 61million-person experiment in social influence and political mobilization. Nature, 489(7415), 295.

Boland, J. A. (2005). Student participation in shared governance: a means of advancing democratic values? Tertiary Education and Management, 11(3), 199-217.

Brown, R. (2013). Everything for sale? The marketisation of UK higher education. London: Routledge.

Brooks, R., Byford, K., \& Sela, K. (2015). The changing role of students' unions within contemporary higher education. Journal of Education Policy, 30(2), 165-181.

Buckley, A., Soilemetzidis, I. \& Hillman, N. (2015). The 2015 student academic experience survey. http://www. hepi.ac.uk/2015/06/04/2015-academic-experience-survey/. Accessed 5 July 2016.

Bynner, J., Dolton, P., Feinstein, L., Makepeace, G., Malmberg, L., \& Woods, L. (2003). Revisiting the benefits of higher education. April: Report to the Higher Education Funding Council of England http://www.hefce.ac. uk/Pubs/RDreports/2003/rd05_03/.

Campbell, D. E. (2006). What is education's impact on civic and social engagement ?," Chapter 3, no. March: 25-126.

Colby, A., Ehrlich, T., Beaumont, E., Corngold, J., \& J. (Eds.). (2007). Educating for democracy: preparing undergraduates for political engagement. San Francisco: Jossey-Bass.

Dennis, C., Louca, V., \& Lemon, J. (2018). Term-time employment and student attainment in higher education. Journal of Perspectives in Applied Academic Practice, 6(1), 28-38.

Dahl, R. A., \& Tufte, E. R. (1973). Size and democracy (Vol. 2). Palo Alto: Stanford University Press.

Dalton, R. J. (2015). The good citizen: how a younger generation is reshaping American politics (2nd ed.). Washington, DC: Congressional Quarterly Press.

Delli Carpini, M. X., \& Keeter, S. (1996). What Americans know about politics and why it matters. New Haven: Yale University Press.

Dekker, P. \& Halman, L. (2003). Volunteering and values, in P. Dekker \& L. Halman(Eds) The values of volunteering. Cross-cultural perspectives (pp.1-18). New York: Kluwer Academic/Plenum Publishers.

Dolan, P. \& Brennan, M. (2016). Civic engagement: an overview. http://www.un.org/esa/socdev/unyin/wyr/2015 /report.pdf. Accessed 24 Feburary 2017.

Eckstein, K., Noack, P., \& Gniewosz, B. (2012). Attitudes toward political engagement and willingness to participate in politics: trajectories throughout adolescence. Journal of Adolescence, 35(3), 485-495.

Erk, J., \& Veenendaal, W. (2014). Is small really beautiful?: the microstate mistake. Journal ofDemocracy, 25(3), 135-148.

Funk, P. (2010). Social incentives and voter turnout: evidence from the Swiss mail ballot system. Journalofthe European Economic Association, 8(5), 1077-1103.

Gardiner, L. (2016). Votey McVoteface: understanding the growing turnout gap between the generations, Resolution Foundation. http://www.resolutionfoundation.org/app/uploads/2016/09/Generational-voting.pdf.

Gerber, A. S., \& Rogers, T. (2009). Descriptive social norms and motivation to vote: everybody's voting and so should you. The Journal of Politics, 71, 178-191.

Gerber, A. S., \& Green, D. P. (2000). The effects of canvassing, telephone calls, and direct mail on voter turnout: a field experiment. American Political Science Review, 94, 653-663.

Giroux, H. (2011). Fighting for the future: American youth and the global struggle for democracy. Cultural Studies - Critical Methodologies, 11(4), 328-340.

Glaeser, E., Giacomo, L., Ponzetto, A.M.\& Shleifer, A. (2007). Why does democracy need education? Journal of Economic Growth,12 (2), 77-99.

Haahr, J. (1997). Nordic area citizenship study-final report. www.europa.eu.int/ comm/education/archive/citizen/copenhagen.pdf.

Halaby, C. N. (2004). Panel models in sociological research: theory into practice. Annual Review of Sociology, $30,507-544$.

Herrnstein, R. J., \& Murray, C. (1994). The bell curve: intelligence and class structure in American life. New York: The Free Press.

Hillygus, S. D. (2005). The missing link: exploring the relationship between higher education and political engagement. Political Behavior, 27(1), 25-47.

Hoskins, B. (2006). A framework for the creation of indicators on active citizenship and on education and training for active citizenship. European Commission: Ispra. 
Hoskins, B., \& Janmaat, J. G. (2016). Educational trajectories and inequalities of political engagement among adolescents in England. Social Science Research, 56, 73-89.

Ipsos MORI (2017). How the voters voted in the 2017 election. https://www.ipsos.com/ipsos-mori/en-uk/howbritain-voted-2017-election.

Janmaat, J. G., Mostafa, T., \& Hoskins, B. (2014). Widening the participation gap: the effect of educational track on reported voting in England. Journal of Adolescence, 37, 473-482.

Keating, A., \& Janmaat, J. G. (2016). Education through citizenship at school: do school activities have a lasting impact on youth political engagement? Parliamentary Affairs, 69(2), 409-429.

Kerr, D., \& Nelson, J. (2006). Active citizenship in INCA countries: Definitions, policies, practices and outcomes. London: QCA.

Kennedy, K. J. (2007). Student constructions of 'active citizenship': what does participation mean to students? British Journal of Educational Studies, 55(3), 304-324.

Knack, S. (1992). Civic norms, social sanctions, and voter turnout. Rationality and Society, 4(2), $133-156$.

Kouba, K. (2018). Determinants of student participation in higher education governance: the case of student turnout in academic senate elections in Czechia. Higher Education, 76(1), 67-84.

Loader, B., Vromen, A., Xenos, M., Steel, H., \& Burgum, S. (2015). Campus politics, student societies and social media. The Sociological Review, 63(4), 820-839.

Luescher-Mamashela, T. M. (2013). Student representation in university decision making: good reasons, a new lens? Studies in Higher Education, 38(10), 1442-1456.

McFarland, D. A., \& Thomas, R. J. (2006). Bowling young: how youth voluntary associations influence adult political participation. American Sociological Review, 71(3), 401-425.

Meyer, D.S. \& Tarrow, S. (eds.) (1998). The social movement society: contentious politics for a new century. Oxford: Rowman \& Littlefield Publishers INC.

Milligan, K., Moretti, E., \& Oreopoulos, P. (2004). Does education improve citizenship? Evidence from the United States and the United Kingdom. Journal of Public Economics, 88(9-10), 1667-1695.

Morgan, J. (2016). Unlimited student recruitment 'transforms' English universities. Times Higher Education. https:/www.timeshighereducation.com/news/unlimited-student-recruitment-transforms-english-universities.

Nie, N., Junn, J., \& Stehlik-Barry, K. (1996). Education and democratic citizenship in America. Chicago: Chicago University Press.

Paterson, L. (2009). Civic values and the subject matter of educational courses. Oxford Review of Education, 35(1), 81-98.

Paterson, L. (2013). Comprehensive education, social attitudes and civic engagement. Longitud. Life Course Stud., 4(1), 17-32.

Pattie, P., Seyd, C., \& Whiteley, P. (2004). Citizenship in Britain: values, participation and democracy. Cambridge: Cambridge University Press.

Persson, M. (2012). Does type of education affect political participation? Results from a panel survey of Swedish adolescents. Scandinavian Political Studies, 35(3), 198-221.

Persson, M. (2014). Testing the relationship between education and political participation using the 1970 British cohort study. Political Behavior, 36(4), 877-897.

Plantan, F. (2002). Universities as sites of citizenship and civic responsibility: final general report. Strasbourg: Council of Europe.

Plutzer, E. (2002). Becoming a habitual voter: inertia, resources, and growth in young adulthood. American Political Science Review, 96, 41-56.

Putnam, R. D. (2000). Bowling alone: the collapse and revival of American community. New York: Simon \& Schuster.

Rosenstone, S. J., \& Hansen, J. (1993). Mobilization, participation, and democracy in America. Macmillan Publishing Company.

Ryšavý, D., \& Bernard, J. (2013). Size and local democracy: the case of Czech municipal representatives. Local Government Studies, 39(6), 833-852.

Roefs, M. (2003). Public participation and perceived (in)justice in South Africa, 1995-2000. PhD Thesis, Amsterdam Free University.

Smets, K., \& Van Ham, C. (2013). The embarrassment of riches? A meta-analysis of individual-level research on voter turnout. Electoral Studies, 32(2), 344-359.

Schafer, J. L., \& Graham, J. W. (2002). Missing data: our view of the state of the art. Psychological Methods, 7, $147-177$.

Sloam, J. (2013). 'Voice and equality': young people's politics in the European Union. West European Politics, $36(4), 836-858$.

TNS-BMRB. (2015). Citizenship education longitudinal survey: wave 6 technical report. Report: Unpublished. Veugelers, W., de Groot, L. \& Nollet, F. (2014). Higher education and citizenship development. In A. Teodoro \& M. Guilherme(Eds). European and Latin American higher education between Mirrors(pp.179-196). Rotterdam: Sense Publishers.

Verba, S., Schlozman, K. L., \& Brady, H. (1995). Voice and equality: civic voluntarism in American politics. Cambridge: Harvard University Press. 
Vromen, A. (2003). 'People Try to Put Us Down...': participatory citizenship of 'Generation X'. Australian Journal of Political Science, 38(1), 79-99.

de Weerd, M., Gemmeke, M., Rigter, J., \& Van Rij, J. C. (2005). Indicators for monitoring active citizenship and citizenship education. Amsterdam: Regioplan Beleidsonderzoek.

Williams, J. (2013). Consuming higher education. Why learning can't be bought. London: Bloomsbury.

Williamson, I., Wildbur, D., Bell, K., Tanner, J., \& Matthews, H. (2017). Benefits to university students through volunteering in a health context: a new model. British Journal of Educational Studies, 1-20.

Winkelmann, L., \& Winkelmann, R. (1998). Why are the unemployed so unhappy? Evidence from panel data. Economics, 65, 1-15.

Publisher's note Springer Nature remains neutral with regard to jurisdictional claims in published maps and institutional affiliations. 